\title{
UJI PERBANDINGAN HASIL PRAKTIK KEWIRAUSAHAAN MAHASISWA PRODI MANAJEMEN DAN AKUNTANSI FAKULTAS EKONOMI UNIVERSITAS PAMULANG
}

\author{
Sunanto*) \\ Email:sunantoapt@gmail.com
}

\begin{abstract}
ABSTRAK
Telah dilaksanakan Uji Perbandingan Hasil Praktik Kewirausahaan Mahasiswa Prodi Manajemen dan Akuntansi Fakultas Ekonomi Universitas Pamulang. Tujuan Penelitian ini untuk mengetahui ada tidaknya perbedaan hasil praktik kewirausahaan mahasiswa antara prodi Manajemen dan Prodi Akuntansi di Universitas pamulang. Penelitian ini menggunakan desain komparatif dengan pendekatan kuantitatif. Populasinya adalah mahasiswa regular $\mathrm{C}$ yang yang tercatat memenuhi syarat (lulus) praktik kewirausahaan pada semester Genap 2017/2018 dengan menggunakan sampel jenuh berjumlah 2227 mahasiswa yang terbagi dalam 66 kelas (48 kelas Manajemen dan 18 kelas Akuntansi). Teknik analisis data dibantu dengan program SPSS dan pengujian hipotesis dengan metode Mann Whitney $U$ test. Hasil penelitian menunjukkan terdapat perbedaan yang signifikan antara hasil praktik kewirausahaan mahasiswa regular C Prodi Manajemen dengan Prodi Akuntansi. Hal ini dibuktikan dengan Uji Mann Whitney dengan nilai Asymp. Sig. (2 tailed) 0,02 <0,05 yang berarti Ho ditolak.
\end{abstract}

\begin{abstract}
The Comparison Test on the Results of Student Entrepreneurship Practices in Management and Accounting Study Program at the Faculty of Economics, Pamulang University have been carried out. The purpose of this study was to determine whether there were differences in the results of student entrepreneurship practices between the study program of Management and Accounting Study Program at Pamulang University. This study uses a comparative design with a quantitative approach. The population is regular $C$ students who are recorded as fulfilling the requirements (graduated) of entrepreneurship practice in Even semester 2017/2018 using saturated samples totaling 2227 students divided into 66 classes (48 Management classes and 18 Accounting classes). The data analysis technique is assisted by the SPSS program and hypothesis testing using the Mann Whitney $U$ test method. The results showed that there were significant differences between the results of regular $C$ student entrepreneurship practices in Management Study Program and Accounting Study Program. This is evidenced by the Mann Whitney test with the value of Asymp. Sig. (2 tailed) $0.02<0.05$ which means Ho is rejected.
\end{abstract}




\section{A. PENDAHULUAN}

Kewirausahaan merupakan keniscayaan dalam konteks ketahanan ekonomi suatu bangsa atau masyarakat, dan merupakan salah satu solusi dalam permasalahan lapangan kerja. David Mc. Clelland mengatakan terkait kewirausahaan bahwa suatu bangsa akan mencapai level kesejahteraan apabila jumlah entrepreneur-nya minimal dua (2) persen dibandingkan dengan total jumlah penduduknya.

Mahasiswa merupakan kelompok generasi muda terdidik yang mempunyai kreatifitas, inovasi dan energi yang relative lebih baik dan mempunyai kemampuan dan potensi yang sangat besar untuk merubah setiap tantangan menjadi peluang. Sikap mental ini merupakan modal dasar untuk menjadi wirausaha muda kampus yang mandiri, unggul dan profitable. Sebagian

Entrepreneurship education yang ada di program pendidikan tinggi kebanyakan bersifat knowledge yang diajarkan di dalam kelas, dan masih relatif jarang yang mempunyai program khusus dalam bentuk praktek kewirausahaan yang sistematis dan terstruktur. Program pendidikan kewirausahaan ini diperlukan oleh mahasiswa sebagaimana temuan Susilaningsih (2015), yang menyimpulkan bahwa pendidikan kewirausahaan di perguruan tinggi diperlukan dalam bidang apapun tanpa memperhatikan bidang yang ditekuni atau profesi seseorang. Temuan Reza Apriliandi dalam penelitian sebelumnya (2018) mengungkapkan bahwa praktikum kewirausahaan mempunyai pengaruh posistif yang signifikan terhadap minat menjadi wirausaha pada mahasiswa Pendidikan Ekonomi di UNY. Kesimpulan dalam penelitian empiris lain menyatakan bahwa faktor lingkungan berpengaruh positif dan siginifikan terhadap minat menjadi wirausaha pada mahasiswa Pendidikan Ekonomi di UNY, dalam Hermin Endratno (2013)

Pusat Inkubasi Bisnis dan Kewirausahaan (PINBIK) Universitas Pamulang menjalankan kombinasi kedua program dalam entrepreneuship education dan training tersebut yaitu apa yang disebut dengan program praktik kewirausahaan mahasiswa (Model Pinbik). Program ini dimaksudkan dalam rangka membangun sikap mental kewirausahaan di lingkungan civitas akdemika khususnya mahasiswa Universitas Pamulang sesuai Surat Keputusan Rektor No. 
129/A/LL/UNPAM/II/2018 tentang Pembelajaran dan Sertifikasi Praktik Kewirausahaan dan Matakuliah sejenis. Dalam tahun pertama penerapan program dilakukan pada mahasiswa Fakultas Ekonomi khususnya mahasiswa program studi (Prodi) Manajemen dan (Prodi) Akuntansi di lingkungan Universitas Pamulang.

Dari hasil praktik kewirausahaan mahasiswa dengan model Pinbik ini akan dibuat kajian apakah ada perbedaan hasil antara mahasiswa di lingkungan prodi manajemen dan prodi Akuntansi Universitas Pamulang. Kajian ini akan menjadi pintu masuk awal untuk penelitian selanjutnya dilihat dari berbagai perspektif, karena hasil praktik kewirausahaan mahasiswa dengan model Pinbik seperti yang diterapkan di Universitas Pamulang ini belum pernah dibuat kajian dan publikasinya dalam literatur ilmiah.

Berdasarkan latar belakang tersebut penulis ingin melakukan penelitian pemasaran dengan judul" Uji Perbandingan Hasil Praktik Kewirausahaan Mahasiswa Prodi Manajemen Dan Akuntansi Fakultas Ekonomi Universitas Pamulang".

\section{B. Perumusan Masalah Penelitian}

Apakah terdapat perbedaan hasil praktik kewirausahaan mahasiswa regular $\mathrm{C}$ pada program studi Manajemen dan Akuntansi Univeristas Pamulang

\section{Tujuan Penelitian}

Ingin mengetahui ada tidaknya perbedaan hasil praktik kewirausahaan mahasiswa regular $\mathrm{C}$ pada program studi Manajemen dan Akuntansi Univeristas Pamulang.

\section{Landasan Teori}

Kewirausahaan menurut Suryana (2011) adalah kemampuan kreatif inovatif sesorang yang dijadikan kiat, dasar, sumberdaya, proses, dan perjuangan untuk menciptakan nilai tambah pada barang dan jasa yang dilakukan dengan keberanian dalam menghadapi risiko. Lebih jauh kewirausahaan dimaknai sebagai "kemampuan kreatif dan inovatif melalui cara-cara yang baru dan berbeda 
yang dijadikan dasar, kiat, dan sumber daya untuk mencari peluang menuju sukses" (Suryana, 2006).

Salah satu kunci untuk mencapai level kewirausahaan yang berhasil adalah memiliki karakter dan kepribadian yang unggul. Faktor individu tersebut mampu membedakan antara wirausaha dengan kebanyakan individu lainnya. Gambaran karakter seorang wirausahawan seperti yang dikutip oleh Alma (2010: 21) adalah orang yang tetap mampu berdiri di atas kemampuan sendiri walau dalam keadaan kritis, bisa survival dan mampu membantu dirinya keluar dari kesusahan yang dihadapi, termasuk mengatasi kemiskinan secara mandiri. Bahkan dalam keadaan biasa, mampu memotivasi dirinya untuk maju, kaya, dan berhasil secara lahir maupun bathin. Dalam konteks inilah, potensi kewirausahaan mahasiswa perlu didorong agar mampu mengaktualisasikan potensi tersebut agar pada saatnya nanti mampu untuk mandiri dan menolong dirinya sendiri dalam menghadapi kesulitan hidup, bahkan mampu membuka peluang kerja bagi orang lain.

Pendidikan kewirausahaan kepada mahasiswa sangat perlu dilakukan abik dalam bentuk pengetahuan maupun praktik. Diharapkan semakin tinggi pendidikan kewirausahaan mahasiswa akan semakin terbuka wawasannya tentang kewirausahaan. Penelitian empiris menyimpulkan bahwa pengetahun kewirausahaan mempunyai berpengaruh pada minat berwirausaha. Dalam penelitian sebelumnya Hermin Endratno ( ) mengungkap temuan bahwa ada hubungan prestasi akademik terhadap intensi kewirausahaan mahasiswa. Demikian juga Innovativeness mempengaruhi intensi kewirausahaan mahasiswa. Temuan Endratno (2013) mengungkap bahwa self confidence berpengaruh terhadap intensi kewirausahaan mahasiswa.

Praktikum secara harafiah berasal dari kata praktik yang berarti pelaksanaan secara nyata apa yang disebut dalam teori (KBBI, 2001). Sedangkan menurut M.Zainuddin (2005) mengartikan praktik atau praktikum sebagai strategi pembelajaran atau bentuk pengajaran yang digunakan untuk membelajarkan secara simultan berbagai kemampuan termasuk kemampuan psikomotorik 
(keterampilan), pengertian (pengetahuan) dan afektif (sikap) dalam menggunakan sarana.

Dalam penelitian terdahulu, Reza Apriliandi (2018) menyebutkan bahwa praktikum kewirausahaan berpengaruh positif dan signifikan terhadap minat menjadi wirausaha pada mahasiswa Pendidikan Ekonomi UNY. Dalam bagaian lain disimpulkan bahwa faktor lingkungan berpengaruh positif dan signifikan terhadap minat menjadi wirausaha pada mahasiswa Pendidikan Ekonomi UNY.

Praktik Kewirausahaan mahasiswa di lingkungan Universitas Pamulang mengikuti model praktik yang dibuat oleh Pinbik. Model praktik Kewirausahaan Pinbipk ini didasarkan pada Surat Keputusan Rektor Universitas Pamulang No. 129/A/LL/UNPAM/II/2018 tentang Pembelajaran dan Sertifikasi Praktik Kewirausahaan dan Matakuliah sejenis. Model Praktik ini merupakan bagian dari tugas matakuliah kewirausahaan atau yang sejenis. Dalam praktiknya model Pinbik ini melibatkan berbagai stake holder diantaranya:

1. Yayasan Sasmita Jaya, yang memberikan ijin dan penyedian prasarana berupa gedung dan sarana untuk praktik kewirasahaan

2. Rektorat, yang memberikan fasilitas dukungan legalitas dalam bentuk surat keputusan Rektor untuk menjalankan program praktik kewirausahaan

3. Pusat Inkubasi Bisnis dan Kewirausahaan (Pinbik) Unpam, yang mengelola program praktik kewirausahaan mahasiswa

4. Program Studi (Prodi), yang memberikan dukungan penyediaan dosen pembimbing praktik dan sekaligus mahasiswa untuk berpraktik

5. Dosen Pembimbing Praktik, adalah dosen yang ditunjuk oleh Prodi untuk menjadi pengampu mata kuliah dan sekaligus sebagai pembimbing praktik.

6. Mahasiswa, dari berbagai program studi di lingkungan Universitas Pamulang yang mendapatkan matakuliah kewirausahaan atau yang sejenis untuk praktik 
7. Kopinmart, salahsatu unit usaha Koperasi Pinbik Universitas Pamulang yang bergerak di bidang ritel perdagangan, menyediakan produk-produk untuk praktik kewirausahaan

8. Para wirausaha dari internal kampus, seperti dosen dan mahasiswa yang telah menjadi wirausaha dan bekerjasama dengan Kopinmart dalam penyedian produk-produk untuk praktik bagi mahasiswa.

9. Pihak eksternal diantaranya prinsipal (pabrikan), distributor yang bekerjasama dengan Koperasi Pinbik Unpam dalam membantu penyediaan produk produk untuk praktik bagi mahasiswa

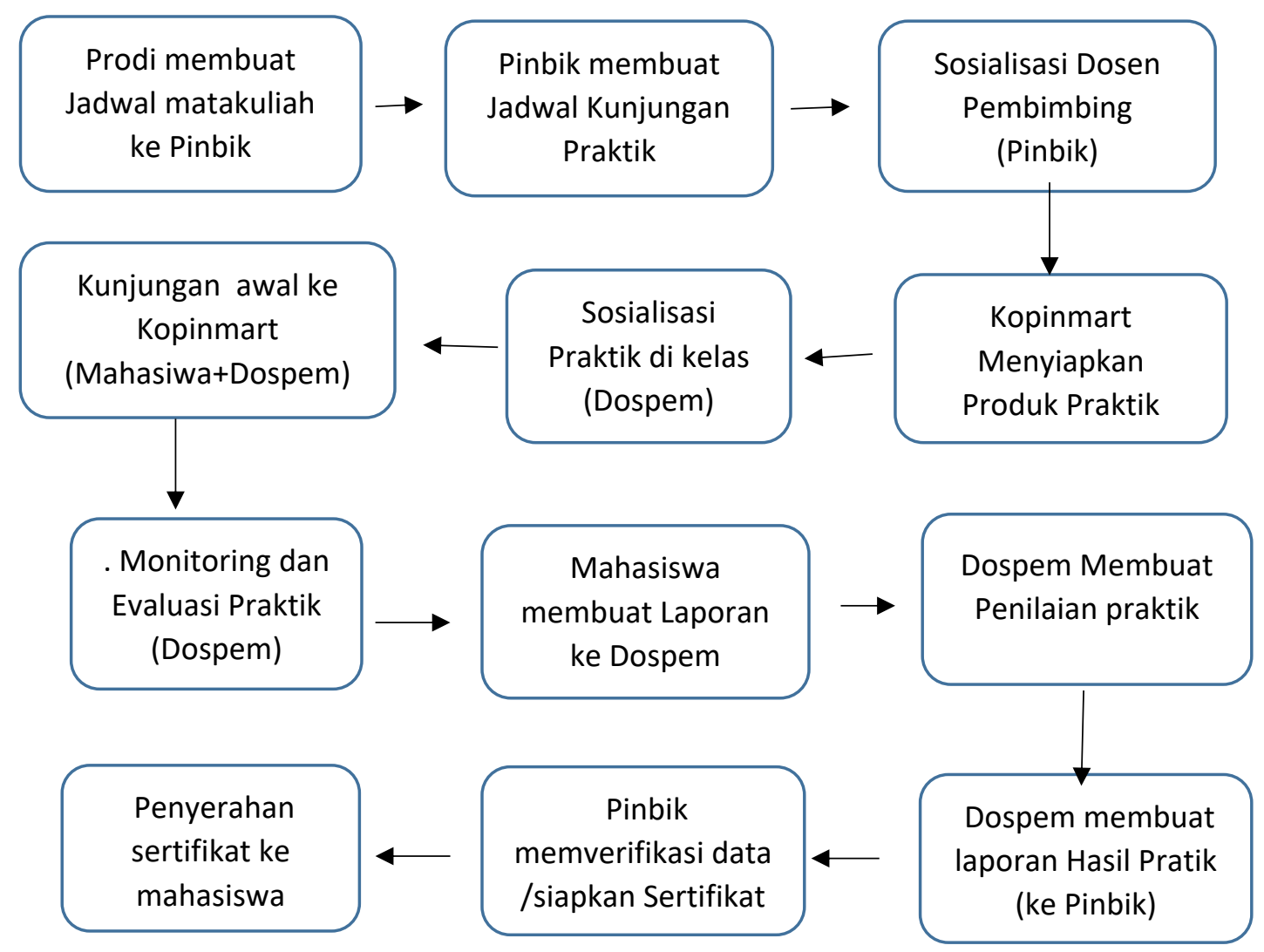

Sumber: Diadaptasi dari Pinbik Unpam

Gambar 3.1 Skema Praktik Kewirausahaan Mahasiswa Model Pinbik 


\section{Hasil Praktik Kewirausahaan}

Menurut KBBI (2001) "hasil adalah sesuatu yang diadakan (dibuat, dijadikan, dan sebagainya) oleh usaha". Hasil dari Praktik Kewirausahaan model Pinbik ada dalam bentuk laporan hasil praktik kewirausahaan yang mengacu pada kemampuan dasar yang harus dimiliki oleh wirausaha yaitu kemampuan di bidang:

Pemasaran, Teknik/Operasi, Keuangan dan Hubungan (Kerjasama dan negosiasi)

Inti dari praktik kewirausahaan model Pinbik ini mengacu pada pengelolaan pasar. Menurut Kotler (2009), inti dari bisnis/usaha adalah menciptakan pelanggan (pasar) yang loyal. Berdasarkan teori Kotler tersebut maka inti dari praktik kewirausahaan model Pinbik ini mengacu pada pengelolaan pasar. Salah satu indikator kuantitatif utamanya adalah hasil penjualan. Sehingga dalam konteks penelitian ini hasil penjualan oleh mahasiswa praktik digunakan sebagai indikator hasil praktik kewirausahaan.

\section{Kerangka Penelitian}

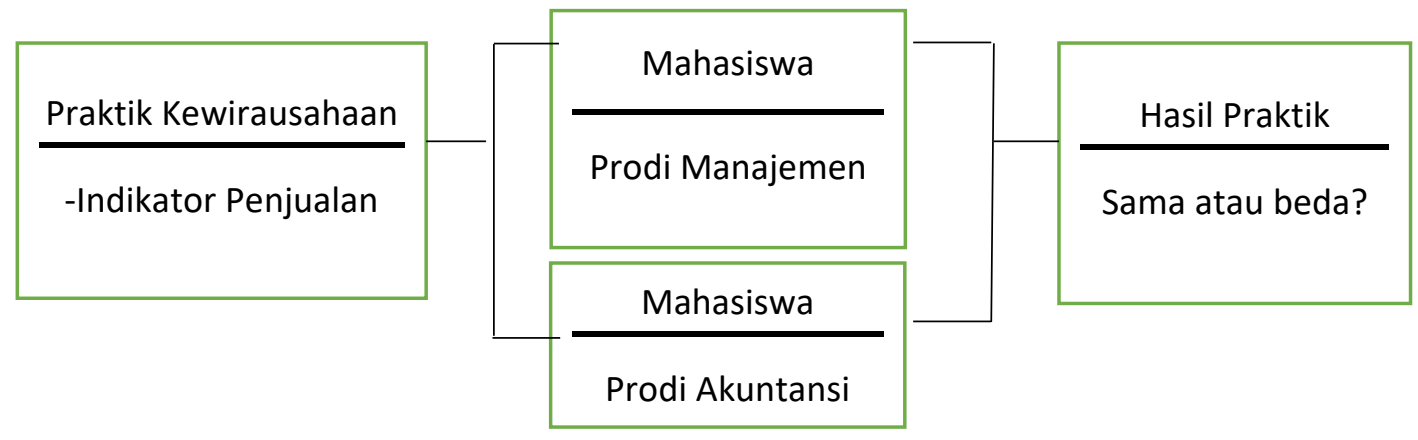

Gambar 2.1 Kerangka Berfikir 


\section{Hipotesis Penelitian}

Dari rumusan masalah serta tinjauan pustaka, diajukan beberapa hipotesis penelitian sebagai berikut:

H0: Diduga tidak terdapat perbedaan hasil praktik kewirausahaan mahasiswa pada prodi Manajemen dan Akuntansi Universitas Pamulang

Ha: Diduga terdapat perbedaan hasil praktik kewirausahaan mahasiswa pada prodi Manajemen dan Akuntansi Universitas Pamulang

\section{E. METODOLOGI PENELITIAN}

Tempat penelitian dilaksanakan di Universitas Pamulang, Fakultas Ekonomi, Program Studi (Prodi) Manajemen dan Prodi Akuntansi. Lokus penelitian yaitu pada Mahasiswa Reguler C Universitas Pamulang dari kedua program studi tersebut yang tercatat memenuhi syarat (lulus) mengikuti program praktik kewirausahaan pada periode semester genap 2017/2018.

Penelitian ini merupakan penelitian komparatif yang sesuai dengan definisi Sugiyono (2011:88) yang menyebutkan penelitian perbndingan ditujukan untuk mengetahui nilai satu variabel atau lebih pada sampel yang berbeda. Penelitian ini menggunakan pendekatan kuantitiatif. Menurut Sugiyono (2011:23) penelitian kuantitatif dinyatakan sebagai penelitian yang datanya berbentuk angka-angka atau data yan bersifat kualitatif yang diangkakan.

Populasi dalam penelitian ini adalah Mahasiswa Reguler C prodi Manajemen dan prodi Akuntansi, Fakultas Ekonomi Universitas Pamulang yang tercatat mengikuti program praktik kewirausahaan pada semester genap 2017/2018. Penentuan jumlah sampel dengan pendekatan sampel jenuh yaitu seluruh populasi yang tercatat dan terbagi dalam kelas praktik dijadikan sebagai sebagai sampel penelitian.

Data dikumpulkan melalui metode dokumentasi. Dokumen yang digunakan adalah data hasil rekap praktik kewirausahaan yang dikeluarkan oleh Pusat Inkubasi Bisnis dan Kewirausahaan (PINBIK) Unpam pada periode semester genap 2017/2018. 
Dalam penelitian ini digunakan analisis deskriptif yaitu dengan menghitung rerata hasil kelas yaitu menghitung total hasil kelas dibagi dengan jumlah mahasiswa yang memenuhi syarat (lulus). Analisis data selanjutnya menggunakan bantuan SPSS.

\section{Uji Hipotesis}

Uji Hipotesis dengan menggunakan Uji Mann-Whitney. Pengujian MannWhitney digunakan dalam pengujian hipotesis nol yang menyatakan bahwa tidak ada perbedaan yang sesungguhnya antara kedua kelompok data dan dimana data tersebut diambil dari sampel yang tidak saling terkait

Pengambilan Keputusan

Dengan taraf alpha 5\%

Jika prob. $\geq 0.05$, maka Ho diterima.

Jika prob. < 0.05, maka Ho tidak diterima.

\section{F. HASIL PENELITIAN DAN PEMBAHASAN}

Penelitian ini dilaksanakan dengan populasi Mahasiswa Unpam dari Prodi Manajemen dan Akuntansi Reguler C yang tercatat memenuhi syarat (lulus) praktik kewirausahaan pada sesmester genap 2017/2018 yang berjumlah 2227 mahasiswa yang terbagi dalam 66 kelas (Terdiri atas 48 kelas manajemen_C dan 18 kelas Akuntansi_C).

\section{Analisis Deskriptif}

\begin{tabular}{|l|r|r|l|r|r|}
\hline Kls C & Prodi & $\begin{array}{l}\text { Rerata Hasil } \\
\text { (Rp) Per } \\
\text { Mahasiswa }\end{array}$ & Kelas C & Prodi & $\begin{array}{l}\text { Rerata Hasil (Rp) } \\
\text { Per Mahasiswa }\end{array}$ \\
\hline 1 & X & 55.658 & 35 & X & 91.966 \\
3 & X & 1.127 .506 & 36 & $X$ & 9.769 \\
4 & X & 352.731 & 37 & X & 19.889 \\
5 & X & 236.119 & 38 & $X$ & 741.686 \\
6 & X & 381.188 & 39 & $X$ & 727.308 \\
& $X$ & 369.017 & 40 & $X$ & 414.243 \\
\hline
\end{tabular}




\begin{tabular}{|c|c|c|c|c|c|}
\hline 7 & $X$ & 161.944 & 41 & $X$ & 474.500 \\
\hline 8 & $x$ & 441.518 & 42 & $x$ & 236.609 \\
\hline 9 & $X$ & 417.270 & 43 & $X$ & 315.721 \\
\hline 10 & $x$ & 296.091 & 44 & $x$ & 621.066 \\
\hline 11 & $X$ & 256.743 & 45 & $X$ & 664.335 \\
\hline 12 & $X$ & 124.988 & 46 & $X$ & 447.445 \\
\hline 13 & $x$ & 156.803 & 47 & $X$ & 805.808 \\
\hline 14 & $X$ & 271.796 & 48 & $X$ & 795.236 \\
\hline 15 & $X$ & 172.392 & & & \\
\hline 16 & $X$ & 272.453 & & & \\
\hline 17 & $x$ & 642.031 & 49 & $\mathrm{Y}$ & 306.956 \\
\hline 18 & $X$ & 363.140 & 50 & $\mathrm{Y}$ & 128.174 \\
\hline 19 & $x$ & 247.569 & 51 & $Y$ & 326.054 \\
\hline 20 & $X$ & 114.720 & 52 & $\mathrm{Y}$ & 96.321 \\
\hline 21 & $X$ & 339.495 & 53 & $\mathrm{Y}$ & 539.704 \\
\hline 22 & $X$ & 141.995 & 54 & $\mathrm{Y}$ & 551.362 \\
\hline 23 & $x$ & 238.864 & 55 & $Y$ & 1.105 .287 \\
\hline 24 & $X$ & 55.267 & 56 & $\mathrm{Y}$ & 1.183 .257 \\
\hline 25 & $X$ & 173.037 & 57 & $\mathrm{Y}$ & 1.550 .973 \\
\hline 26 & $X$ & 843.771 & 58 & $\mathrm{Y}$ & 1.245 .716 \\
\hline 27 & $X$ & 836.493 & 59 & $Y$ & 1.058 .876 \\
\hline 28 & $X$ & 22.992 & 60 & $\mathrm{Y}$ & 1.038 .694 \\
\hline 29 & $X$ & 163.626 & 61 & $Y$ & 703.554 \\
\hline 30 & $x$ & 380.387 & 62 & $\mathrm{Y}$ & 964.423 \\
\hline 31 & $X$ & 116.093 & 63 & $\mathrm{Y}$ & 374.662 \\
\hline 32 & $X$ & 284.774 & 64 & $\mathrm{Y}$ & 1.114 .511 \\
\hline 33 & $X$ & 581.204 & 65 & $\mathrm{Y}$ & 282.222 \\
\hline 34 & $X$ & 143.555 & 66 & $\mathrm{Y}$ & 433.122 \\
\hline
\end{tabular}

Tabel 4.1: Deskriptif Data Hasil Praktik

$X=$ Prodi Manajemen, dan $Y=$ Prodi Akuntansi

Sumber: Data diolah (Pinbik Unpam) 


\section{Pengujian Hipotesis}

Dengan Uji Mann Whitney U

Tabel 4.1: Hasil Deskriptif Ranks

\begin{tabular}{|r|l|r|r|r|}
\hline & Prodi & N & \multicolumn{1}{|c|}{$\begin{array}{l}\text { Mean } \\
\text { Rank }\end{array}$} & Sum of Ranks \\
\hline \multirow{2}{*}{ Hasil_Praktik_KWH } & Manajemen_C & 48 & 29.02 & 1393.00 \\
& Akuntansi_C & 18 & 45.44 & 818.00 \\
& Total & 66 & & \\
\hline
\end{tabular}

Dari tabel 4.1 terlihat gambaran jumlah kelas total 66 kelas yang terdiri dari Manjemen_C sebanyak 48 kelas dan Akuntansi_C berjumlah 18 kelas.

Pengujian Hipotesis dengan Uji Mann Whitney seperti dalam tabel di bawah

Tabel 4.2: Uji Hipotesis

Uji Statistik

\begin{tabular}{|l|r|}
\hline & Hasil_Praktik_KWH \\
\hline Mann-Whitney U & 217.000 \\
Wilcoxon W & 1393.000 \\
Z & -3.096 \\
Asymp. Sig. (2-tailed) & .002 \\
\hline
\end{tabular}

a. Grouping Variable: Prodi

\section{Hipotesis:}

Ho: Diduga tidak terdapat perbedaan yang signifikan hasil praktik kewirausahaan mahasiswa regueler C pada Prodi Manajemen dan Akuntansi Universitas Pamulang 


\author{
Ha: Diduga terdapat perbedaan yang signifikan hasil praktik \\ kewirausahaan mahasiswa regular C pada Prodi Manajemen dan Akuntansi \\ Universitas Pamulang \\ Dengan alpha 0,05 atau $5 \%$ \\ Daerah kritis: \\ Ho tidak diterima jika nilai p. Sig. (2 tailed) $<0,05$
}

\title{
Hasil:
}

Karena nilai p. Sig. (2 tailed) 0,02<0,05 maka Ho tidak diterima yang berarti terdapat perbedaan yang signifikan antara hasil praktik kewirausahaan mahasiswa regular C Prodi Manajemen dan Prodi Akuntansi Universitas Pamulang

\section{Kesimpulan}

Terdapat perbedaan yang signifikan antara hasil praktik kewirausahaan mahasiswa regular C Prodi Manajemen dan Prodi Akuntansi Universitas Pamulang. Hal ini dibuktikan dengan nilai p. Sig. (2 tailed) 0,02<0,05 maka Ho tidak diterima.

\section{Saran}

1. Dari hasil uji ternyata terdapat perbedaan yang signifikan hasil praktik antara mahasiswa regular C Prodi Manajemen dan Prodi Akuntansi, maka diharapkan mahasiswa regular $\mathrm{C}$ prodi manajemen dapat lebih diberdayakan dalam meningkatkan hasil praktiknya melalui berbagai pendekatan dari seluruh stakeholder yang terkait. Untuk mahasiswa regular C Prodi Akuntansi dapat terus ditingkatkan potensi hasil praktiknya.

2. Untuk penelitian selanjutnya diharapakan bisa dikaji faktor-faktor yang berpengaruh terhadap hasil praktik kewirausahaan mahasiswa, misalnya faktor individu, lingkungan, serta dosen pembimbing praktik. 


\section{G. DAFTAR PUSTAKA}

Aisy, N. 2017. Peran Strategis Praktik Kewirausahaan Dalam Penumbuhan Sikap Entrepreneurship Mahasiswa Program Studi Pendidikan Akuntansi FKIP UMS, Program Studi Pendidikan Akuntansi FKIP UMS

Endratno H., Widhiandono H. 2013. Intensi Kewirausahaan Mahasiswa(Studi Perbandingan Antara Mahasiswa FE UMP Dan FE UNSOED. Prodi Manajemen Fakultas Ekonomi Universitas Muhammadiyah Purwokerto.

Fahmi, Irham. 2013. Kewirusahaan. Teori, Kasus, dan Solusi. Bandung: AlfaBeta

Istijanto. 2009. Aplikasi Praktis Riset Pemasaran. Jakarta: Gramedia Pustaka Utama.

Kotler, Philip, and Keller K. L. 2009. Marketing Management. $13^{\text {th }}$ Edition. New Jersey. Pearson, Prentice Hall.

Kotler, Philip, dan Keller K. L. 2009. Manajemen Pemasaran. Terjemahan, Edisi Ketigabelas. Jilid 1. Jakarta: Erlangga

Malhotra, Naresh K. 2010. Riset Pemasaran. Pendekatan Terapan. Edisi Keempat. Jakarta: Indeks Group Gramedia

Sherlywati, et all. 2017, Analisis Perbandingan Kemampuan Kewirausahaan Pengusaha Perempuan Dan Laki-Laki: Studi Pada Umkm Di Kota Bandung, Jurnal Manajemen Maranatha, Program Studi Manajemen, Fakultas Ekonomi, Universitas Kristen Maranatha. Volume 16, Nomor 2, Mei 2017, Pp 133-212. Issn 1411-9293 | E-Issn 2579-4094.

Sugiyono. 2012. Metode Penelitian Kuantitatif Kualitatif dan R\&D. Bandung: AlfaBeta

Suryana, Kewirausahaan. 2006. Pedoman Praktis: Kiat dan Proses Menuju Sukses. Jakarta: Salemba Empat.

Susilaningsih. 2015. Pendidikan Kewirausahaan Di Perguruan Tinggi: Pentingkah Untuk Semua Profesi?, Jurnal Economia, Volume 11, Nomor 1, April 2015, Universitas Sebelas Maret Surakarta, Indonesia 
Widjaya, T. 2011. Cepat Menguasai SPSS-19. Jakarta: Cahaya Atma. Yohnson. 2003. Peranan Universitas Dalam Memotivasi Sarjana Menjadi Young Entrepreneurs, Jurusan Ekonomi Manajemen, Fakultas Ekonomi - Universitas Kristen Petra, http://puslit.petra.ac.id/journals/management/ 